Original article

\title{
THE EGYPTIAN ROLE IN ULLAZA DURING THE SECOND MILLENNIUM B.C
}

\author{
Abo-Eleaz, M. \\ History dept., Faculty of Arts, Minia Univ., Minia, Egypt. \\ E-mail:mohyaboeleaz@yahoo.com
}

\begin{abstract}
Egypt had an extremely vital role in the Eastern Mediterranean coast since the beginning of the third millennium BC, allowing Egypt to control and impose its political and ideological domination on the surrounding cities to obtain the products that Egypt lacked. Thus, many of the names of the Syrian cities were mentioned in the Egyptian records, including the city and port of Ullaza. Because of its strategic location and economic wealth, Ullaza became the focus of the forces that competed Egypt in its domination, including the Mittani, Hittites, and Kingdom of Amurru during the second millennium BC.
\end{abstract}

Keywords: Ullaza, The Egyptian Mediation, Byblos, Garrison, Amurru.

\section{Introduction}

Ullaza is one of the ancient cities that were mentioned in the Egyptian records. For example, in the Middle Kingdom, it was found in the inscription of Khnumhotep $\mathrm{III}^{(\mathrm{a})} w 3 t j$ [1], in the Excretion texts $=0$ (Iwti) [2], $=0$ (Iw3ti ${ }^{2}$ [3]. In the New Kingdom, it was found in the annals of Thutmose III

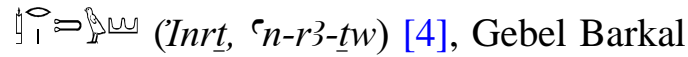
stela (Iwn-r3-t ) [5], and Asiatic list of Thutmose III 11 [6]. It was repeated nine times in Amarna letters in these formulae URUUl-la-asa ${ }^{\mathrm{KI}}$ [7], ${ }^{\mathrm{URU}} \mathrm{Ul}-\mathrm{la}$ aš-š ${ }^{\mathrm{KI}}$ (EA.61:3), and ${ }^{\mathrm{URU}} \mathrm{Ul}$-la-aš-sa ${ }^{\mathrm{KI}}$ (EA.140:19). In addition, it was found in the texts of Seti I lilli w Iwnrt and the records of the topographical lists of Ramrses II in the inscriptions of Karnak, Luxor, Ramesseum, and Nahr el-Kalb $[1,8]$. Its location is unknown. Alt and Noth agree that it is a city on the
Phoenician coast [9]. Bryce argues that it is the "Late Bronze Age city on the Levantine coast near the southern frontier of Amurru" [10]. Misler specifies its location about $40 \mathrm{Km}$ to the north of Tripoli [11], while Sethe suggests that it is located near the city of Tyre [2]. It can be identified with Uzu or Uso which was found more than once in Amarna letters [7] and Papyrus Anastasi I [12]. Albright argues that Tell Qazil lies on the right bank of Nahr el-Abraš, $8 \mathrm{~km}$ north of the mouth of the Eleutherus [13]. Dussaud identifies it with Qala't er-Rus, about $25 \mathrm{Km}$, South of Ras Shamra[14]. Gauthier suggests that it is located near Merna River [15]. Others consider it to be near Sumar, probably at the mouth of the Nahr el-Barid and near the Orthosia of the Greeks [16]. The text more precisely locates the site 
on a body of water ol $=N s-r 3-n 3$ (formerly misread Mrn) in Annals of Tuthmosis III. This indicates a stream, rather than the coast. Thus, it is logically linked with the Eleutheros itself [17]. Smith and others believe it to be U-luzi; a harbor in Eastern Cilicia. It may also be identical with $U$-ul-za-at, called by the Hittites Ukulzat ${ }^{(\mathrm{b})}$ or Ugulzit [18]. Additionally, others identify it with Ullišum city that was conquered by the Akkadian king Naram- Sin [19]. It could be argued that Ullaza was a populated city at least by the end of the third millennium BC. It also had a port on the
Phoenician coast. Additionally, it was $50 \mathrm{~km}$ from north Byblos [1]. It could be compared to Artousia. It was also located on the banks of Nahr el-Bared, 14 $\mathrm{km}$ north of Tripoli. It could be claimed that the river Merna or $N s-r 3-n 3$, mentioned in some sources was the name of Nahr el-Bared in ancient times, fig. (1) [20]. Artousia is preserved in a place called Arthusi; a maritime city of secondary importance. It did not mint a coin until the first century BC during the reign of Emperor Nero [21].

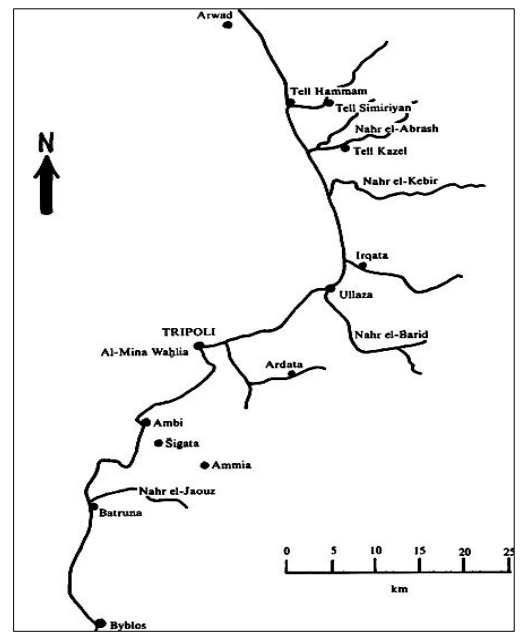

Fig. (1) Shows map of north Phoenician coast [22]

\section{The Egyptian role during the first half of the Second millennium BC}

It has already been mentioned that

Ullaza first appeared in the Egyptian records in the inscription found in Dahshur by Khnumhotep III despite the difficulties that faced the scholars in handling this inscription as it was highly fragmented. It described an Egyptian mission led Khnumhotep - the overseer of an expedition of sailors - to Ullaza to bring the cedar. How-

\subsection{The Egyptian transition to Ullaza}

To answer the first question, about the reasons for the Egyptian shift to bring cedar from Ullaza and not Byblos. In my Ph.D. study, I concluded that the relations between Egypt and Byblos during the first half of the $12^{\text {th }}$ Dynasty were dramatically strained because of the military campaign of King Amenemhat II on the Phoenician coast ever, the Egyptian mission faced many problems. The text states that: " [What was done was] to reach [Retjenu in order to] get cedar of the harbor [of Ullaza]" [1]. This text raises some questions about the reasons why Egypt resorted to Ullaza and did not go to the port of Byblos, the main port, to bring cedar and the problems they faced.

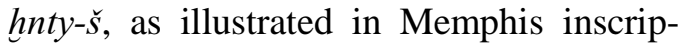
tion. It returned with the tribute including great numbers of goods in ten ships. This illustrates why the name of Byblos was mentioned in the Excretion texts [23]. It was clearly condemned by the tribes of Byblos. Albright describes them as "departed peoples". They lived in the areas surrounding the city of Byblos [24]. 
It seems that they refused the Egyptian presence because of the previous campaign. They also caused major problems that led to prevent cedar's exportation to Egypt, especially, they controlled the forest areas (Hinterland) around Byblos ${ }^{(\mathrm{c})}$. The Egyptian texts described this area as the key to access the "land of God", where cedar grown. As a result, Egypt turned to Ullaza to get cedar. During this period, the Egyptian relations developed in the

\subsection{The conflict between Byblos and Ullaza}

To answer the second question that related to the difficulties that Khnumhotep III faced in his mission to Ullaza, it is clear that it was unable to reach the port of Ullaza. He said [What was done / What. .. did] was to go down? perhaps [ $r$ dpwt] "into ships? [1]. It was followed by the landing-place of Byblos $t 3 z] m 3$ $n k[b] n j[26]$. This was directly caused by a conflict between Ullaza and Byblos. It seems difficult to conclude its reason because the inscription was fragmented. However, its remaining can be analyzed as follows: It states that the son of the Byblite king and 100 soldiers. They seemed to be besieged the city to fight its ruler [27]. In my opinion, this number of soldiers compared to the population of Byblos indicated that the conflict of the two cities was huge and for a serious reason. According to some scholars, in the Middle Bronze Age, the inhabitants of Byblos were 1500- 2000 people because of the small size of the city (5-7 hectares) [28]. Wastlhuber suggested that "there seemed to be a conflict between the kingdoms of Byblos and Ullaza caused by the son of the Byblite king being somehow involved. He was either kidnapped by Ullaza or he defected to the hostile city" [27]. In my opinion, defecting is more likely. This could be compared to what happened in Amarna, when Ilirabih defected on Rib-Adda (EA.139, 140). After the failure of Khnumhotep III to land in the port of Ullaza, the first choice was to go to Byblos. He mentioned in his inscription: "the landing-place of Byblos", cities of the Phoenician coast, including Ullaza. Until that time, it had not been clearly mentioned in the Egyptian texts. Memphis inscription shows the names of unknown and questionably read cities, such as 'Iwii and 'Tssii. Dantong assumes that 'Iwil referred to Ullaza [25]. If this assumption was true, Egypt found a new port for wood imports. This explains the transition of Khnumhotep III to Ullaza.

it was not surprising that the ruler of Byblos refused his landing in the port because of the campaign of Amenemhat II on the Phoenician coast. Thus, he asked: " What the overseer of an expedition of sailors did [was to enter the house of the ruler] of Byblos, the malku ". Then, he asked: "What is it? Are you (headed) to the harbor of Ullaza? ${ }^{(\mathrm{d}) "}$ [1]. This was a shocking reply. To investigate its reasons, the author believes that it was not because of Amenemhat's II campaign because but it was directed to the ruler of Byblos in the first place but to the Bedouin residing around. It was mainly refused because it was originally directed to Ullaza, which it was at war with Byblos at this time. This angered malku of Byblos. Therefore, the Egyptian commander invokes the former relations between Egypt and Byblos in the $12^{\text {th }}$ Dynasty. He said: "The overseer of an expedition of sailor] s [said to him], "Now, when [the elder god], the Dual King Sehetepibre, justified and took possession of the two banks. [Every] foreign land worked for him, and the malku [of Byblos let] us moor at Byblos" [1]. It seems that when the malku of Byblos felt at ease of the goodwill of the Egyptian mission, he agreed on their stay in Byblos in order to mediate between Byblos and Ullaza. The text also showed that one of the two kings- likely malku of Byblos- sought the assistance of the pharaoh - either Senusret II or Senusret III - in a letter. He received a positive answer [27]. 


\subsection{The Egyptian mediation}

During the Old Kingdom, the pharaohs sent many royal envoys in various missions to Byblos. They were almost commercial missions: (1) $t 3-s n$ [29] (2) $N f r-s s ̌ m-R^{e}$ [30]. (3) Khui [31]. (4) Iny [32]. The previous missions did not face what was faced by the mission of Khnumhotep III. It was even forced to diplomatically intervene in the conflict between the two cities. In this sense, the political situation in the Levant apparently changed. Khnumhotep account seemed to depict for later periods. It could also allude to a modification of the dynamics of the access to this specific resource. A diminished ascendancy of Egypt on Byblos and its hinterland might prompt more diplomatic efforts for the supply of the product that was naturally granted in the past [33]. But in this case, a serious development took place in the mission of the Egyptian envoy. Although he sent a trade mission to bring cedar, it was transformed into a diplomatic one. The Egyptian delegation was sent with a message to the king of Ullaza. The inscription states: "To the north of Ullaza [via one of] the ships of the Egyptians who should speak to the ruler of Ullaza

\subsection{Results of the Egyptian mediation}

After the war against Ullaza, the relationship dramatically changed with 2.4.1. Golden gifts policy

The diplomatic gifts were offered of gold instead of stone vessels [35]. They were exclusively dedicated 2.4.2. The Egyptian title H3it- ${ }^{-}$

The meeting of Khnumhotep and the king of Byblos seemed to have taken place in a time when the Byblite rulers still used Semitic titles, such as malku [38]. They did not designate themselves with the Egyptian hitt- ' ${ }^{t}$ th't $^{2}$ time [27]. Before this case, it was clear that there were only economic relations that were not developed into deeper diplomatic relations between Egypt and Byblos. on a mission [for Byblos]."Look, it is the ruler, the malku, has sent a word via this ship to the Egyptian speakers at [...]. [1]". Did diplomatic efforts to mediate between the two cities succeed? It seemed that the diplomatic efforts failed. So, the text seemed to refer to an Egyptian army dispatched overland to Lebanon across the eastern Delta canal that was considered the border between Egypt and "the Asiatic's land." If this took place under Senwosret III, as it seemed likely, it was the same expedition, as recorded in the stela of Khusobek. It referred to "a miserable Retjenu" that fell to the Egyptian army [34]. To conclude, these were the reasons for the Egyptian intervention in favor of Byblos:

* The city was in close contact with Egypt throughout its history.

* It seemed that the elements that led to the ill-Egyptian relations with Byblos in the first half of the $12^{\text {th }}$ Dynasty they were the nomadic peoples who threatened the interests of Egypt. It was mentioned in the execration texts and unclear passage of Khnumhotep stating: "for those things said by the Asiatic Bedouin [...]" [1].

Egypt. Two results could be concluded from the Egyptian mediation:

to the royal family in Byblos [36], especially during the reign of King Amenemhat III and IV [37].

The rulers of Byblos referred to themselves as malku. The Egyptians were addressed as $h K 3$. After the war against Ullaza, the relationships dramatically changed. The Byblite rulers discarded the Semitic titles and designated themselves with the Egyptian h3it-?. In addition, their names and titles were written in hieroglyphs [39]. 


\section{The Egyptian Role during the $2^{\text {nd }}$ Half of the $2^{\text {nd }}$ Millennium BC. \\ 3.1. Mittani domination of Ullaza}

Since the mid-sixteenth century, Mittani was able to control many Syrian cities. It had the strongest influence in most northern and central Syria cities, including Aleppo, Nia, Mukishe, Qatna, and Tunip. During the $15^{\text {th }}$ century BC, especially during the reign of the Mittani king "Saushtatar", a contemporary of Tuthmosis III, the over lordship of Saushtatar of Mittani was shown by two legal texts concerning lawsuits. The king Mittani was mentioned as the highest authority. It was also mentioned in his treaty with "Ir Adad/Teshup" of Tunip. He referred to the oath sworn to the king of the "Hurrian warriors"[40]. The pharaohs of the early $18^{\text {th }}$ dynasty penetrated into Syria and established their rule at least in the southern parts of the country and on the Syrian coast.

\subsection{The Egyptian domination of Ullaza}

During the reign of King Thutmose III and after the battle of Megiddo, the land-route was opened to Syria. $\mathrm{He}$ started his next $\left(1 . e .5^{\text {th }}\right)$ campaign from the Akkar Plain [42]. In the year 29 of his role (1476 BC.), he headed his army up to the Phoenician coast. He seized Ullaza and Ardata, and captured all the garrison that Tunip had set up on the Phoenician coast. As the timing of the campaign was set to coincide with the harvest season, it shipped large quantities of wheat, wine, and fruit on board of the ships to Egypt. In his annals, Tuthmosis III mentioned: "Regnal year 29. Now [His] Majesty [was in Dj]ahy, destroying the foreign lands which had rebelled against him on his 5th victorious campaign. Then His Majesty plundered the town of War[e]t (Ullaza)" [17]. In next year, the Egyptian army returned on board of the ships docked in Byblos to attack Kadesh, Sumur, and Ardata. The king of Tunip took advantage of the pharaoh's celebration of his first sedfestival. He fortified Ullaza once again and appointed his son as a commander.
When the Egyptian campaigns in Syria were taken up again during the reign of Thutmose III, the Egyptian army had to fight against Mittanian troops which gained a foothold in northern Syria during the period of Egyptian inactivity [40]. They appeared to exist in Tunip, through the horses and warriors that distinguished the Mittanians, which would be part of the Egyptian spoils. But what was the relation between Tunip and the Mittani over lordship of Ullaza?. In the $15^{\text {th }}$ century BC., Ullaza entrusted the King "Saushtatar" because of the control of the king of Tunip, or it, at least, entered an alliance with the city of Tunip under the protection of Mittani. One of the manifestations of that control was that the king of Tunip set up a military garrison [41].

Thus, Tuthmosis III came back under the walls of Ullaza and seized Ullaza in 31 year: "Plunder brought from the town of Ullaza which is on the bank of Nsr3-n3, Commander [of the vile army (?)] of the son of the doomed one of Tunip". Then, the Phoenician coast became safe to Tripoli in the north. In addition, Tuthmosis was determined to retain control over and installed a garrison in Ullaza. $\mathrm{He}$ supplied the port of Ullaza, according to his annals "with everything good", including bread, oils, incense, wine, honey, and all kinds of fruit. Ullaza also played an important role in bringing cedar to Egypt every year. Tuthmosis III mentioned in his annals: "Every year, my army, the standing force in Ullaza, annually comes [to My Majesty (?) with cedar. My Majesty's forcible confiscation, through the counsels of my father [Amunre] who consigned all the foreigners to me." [17]. Several things could be noted in the campaigns of Tuthmosis against Ullaza: (1) It represented the food basket of raw materials, e.g. bread, grains, wine, honey, and fruit to the Egyptian royal army neces- 
sary for future campaigns [5]. (2) Until the campaign of year 31, Thutmosis III did not take care about the establishment of a military garrison in Ullaza, but he destroyed its fortresses. After the rebellion of its population against the Egyptian presence, and the entrenchment of the son of Tunip prince in it, Tuthmosis set up a military garrison in Ullaza. (3) It was chosen as one of the Egyptian garrisons in the Levant like Kumidi, Megiddo, Beth Shan, Jaffa and Sumur [5]. It was ruled by an employee entitled" overseer of the foreign land" [43] because of its important strategic location and to ensure the stability of the ruling system. The role of local princes in monitoring was shown to ensure the continued supply of goods to Egypt. Thus, it was the duty of these garrisons to perform their compulsory work [44]. Ullaza was the garrison in the north responsible for the Lebanese cedar. It cut and transported wood to the Syrian coast, as the Royal annals stated," Lebanon's leaders"[5]. Therefore, some scholars suggested that the fortress built by Tuthmosis III in Lebanon was in Ullaza. It is an assumption because this fortress was mainly: A military garrison, to maintain the Egyptian presence in the port to secure access to the city at any time, and to supply Egypt with wood from the surrounding forests. It continued to play its role during the reign of Tuthmosis III until the year 47. According to the Gebel Barkal stela, an Egyptian garrison stationed at Ullaza and was involved in procuring wood to be sent to the Temple of Amun in Egypt [41]. It was the key responsible for the supply of cedar wood. Because of the presence of a garrison, it was the starting point of Tuthmosis III during his $8^{\text {th }}$ campaign, fig. (2) [45]. (4) If Redford's restoration of the traces is correct, the Egyptians encountered a band of Apiru at Ullaza. This would be one of the earliest references to these people in Egyptian sources [17]. (5) Ullaza allied with Tunip. Thus, it was indirectly connected to Mittani. It could be inferred that Ullaza received support from Tunip and Mittani, where it was among the spoils of the Egyptian campaign in the year 31 from Ullaza: 26 horses, and 13 chariots [46]. (6) Which confirmed the existence of support Mittani in two campaign against Ullaza, the number of participants of soldiers against Egypt as reported in the annuals?.

\begin{tabular}{|c|cc|c|}
\hline Dead (served hands) & Prisoners & Place & Year \\
\hline & 329 & Ullaza & 29 \\
\hline & 492 & Ullaza & 31 \\
\hline & 80 & Euphrates & 33 \\
\hline & 90 & Nahrin & 34 \\
\hline & 10 & Nuhasse & 35 \\
& 50 & Nahrin & 38 \\
& 691 & & 42 \\
\hline
\end{tabular}

The number of soldiers in Ullaza during the two camp-aigns was estimated by 821 soldiers, while that of (Euphrates and Nahrin) under the leadership of the Mittanians 781 soldiers. They were close to the force that allowed us to compare them, indicating the support between Ullaza, Tunip and Mittani [47].

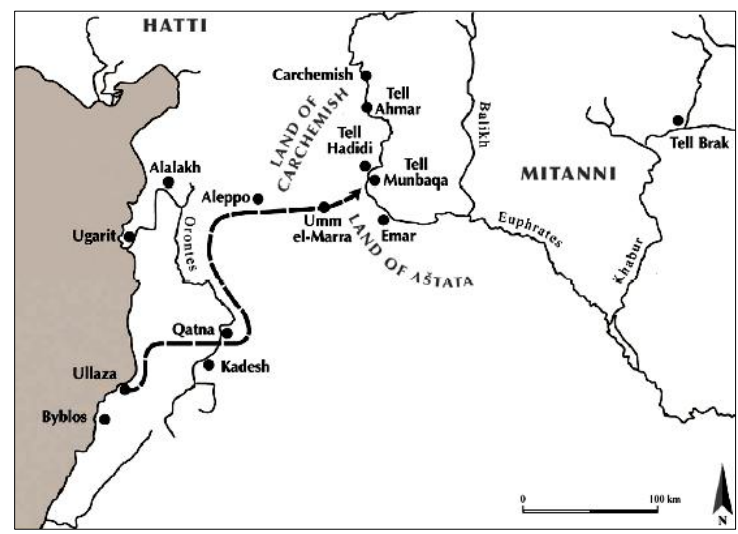

Figure (2) Shows Ullaza starting point of the $8^{\text {th }}$ campaign [45] 


\subsection{Amorite domination of Ullaza}

The Egyptian domination of Ullaza continued from the time of Thutmose III to Thutmose IV. However, Amenhotep III's policy in neglecting the Egyptian states in the Levant directly caused the emergence of local leadership and alliances, supported by regional forces. In addition, "Abdi Ašrati" appeared as a strong force. He exploited the desire of "Apiru" tribes in the expansion and the collection of spoils and robes. They might had common origin [48]. Therefore, he gathered them under his leadership, made an alliance with the Mittanians,(EA.60:10-15; EA.89: 21-22; EA.95:27-31) and began to build a state at the expense of the Egyptian states in the Levant. Because the Egyptian administration was based on the rule of each city through its local chief who oversaw the Egyptian royal commissioner, Ullaza was subject to the royal commissioner " ma-ba-na-ti" who resided in Sumur (EA.60:10-25). Abdi Ašrati tried to take control of Ullaza. He asked Amenhotep III to obtain the privileges and charges assigned to the royal Egyptian commissioner ${ }^{\mathrm{m}} \mathrm{Pa}$-ba-na-ti to protect Sumur and Ullaza, especially in times of absence from that country when traveling to Egypt. Thus, he sent to Amenhotep III, saying: " there is Paba-na-ti, my commissioner, may the king, the sun, ask him if I do not guards Sumur and Ullaza, when my commissioner is on a mission of the king, the sun, then I am the one who guards the harvest of the grain of Sumur and all the lands for the king, my sun, my lord, may the king, my lord, know me and entrust me to charge of Pa-ba-na-ti my commissioner" (EA.60:20-30). It could be concluded that Amenhotep III agreed. He dealt with these powers freely and violated the oath, from the point of view of Rib-Adda who he said: "Now, indeed, Sumur, My lord's court and his bedchamber, has been joined to him. He has slept in the bedchamber of my lord, and opened the treasure room of my lord, and yet he the kings has done nothing"(EA.84:27-30). Therefore, the Egyptian military sent a campaign to Sumur. It resulted in killing Abdi Ašrati in mysterious circumstances (EA.101:20-30). Accordingly, Ullaza returned to Egyptian domination. The sons of Abdi Ašrati tried, after a period of escape and dispersal, returning the cities that were under the rule of their father. This was greatly aided by the death of Amenhotep III, and the transition of the throne Amenhotep IV, who largely departed from areas of influence in the Levant. So, they started to restore their father's property. Their first victory was the success of ${ }^{\mathrm{m}} \mathrm{Pu}-\mathrm{Ba}$-ab-la- a son of Abdi Ašrati- who seized Ullaza. Hence, Rib-Addi told Amenhotep IV: " May the king, my lord, know that Pu-Ba-abla the sons of Abdi Ašrati, has occupied Ullaza "(EA.104:7-9). Then, he asked the king to send troops: "they have taken Ullaza. If in these circumstance you do nothing Sumur and kill the commissioner and the auxiliary force "(EA.104:3034). He repeated this invoice (EA.105:2224; EA.109:15-16). However, what was strange that the inhabitants of Ullaza joined a multi-cities alliance, under the leadership of the sons of Abdi Ašrati, against Byblos and the cities that were loyal to Egypt. Rib-Addi said: "The cities of Ampi, šigata, Ullaza, and Arwada are at war with me"(EA.104:40-43). Moreover, this alliance was primarily directed against the Egyptian garrison in Ullaza that had to flee to Byblos. Rib-Addi mentioned: "The Egyptian that got out of Ullaza are now with me, but there is no grain for them to eat "(EA.105:84-87). This strongly indicated the activity of the Apiru among the population of Ullaza - their early appearance in Ullaza during the reign of Tuthmosis III- which caused that Ullaza population to revolt against the Egyptian garrison. Perhaps, they were broadly desc-ribed as wanderers [41]. Thus, Ullaza was not temporarily under the Egyptian domination; from Aziru to Benteshina [40]. 


\subsection{Return of Ullaza to the Egyptian domination}

Ullaza remained under Amuru's kingdom during the reign of Aziru. Thus, it moved their subordination to rule the Hittites, especially after the alliance of Aziru with Suppilulima I [49]. During the $19^{\text {th }}$ Dynasty, Sity I decided to restore Egypt's influence in the Levant, especially the strategic areas and ports. In the first year, he could then freely go onward into the Hittite-dominated areas, attacking the coastal cities of Amurru right up to Ullaza. He arrived after a journey of 4 days $=$ ca. 54 miles. Confirming its loyalty, he consequently took over to the Egyptian side the coastal cities north from Ullaza such as Irqata and Sumur, Afterwards; he sought to dominate the most important buffer states. El-Saady also assumed that Sety I launched his attack from Ullaza directly to Qadesh. It took 2 days. Then, he went back to Ullaza. He stayed there for a time to confirm his victory and to crush any attempted counter-attack, particularly as he did not march to the north of Amurru [50]. It could be said that during Sity I's stay in Ullaza, he proved his renewed contact with Phoenicia, as shown by the scene of their hewing timber in the pharaoh's relief scenes [51]. In the $5^{\text {th }}$ year of Ramesses II's reign, he took his forces up to the coast of Sumur, re-imposing the Egyptian control of Ullaza. This domination continued. In the $8^{\text {th }}$ year campaign, his attacks on Ullaza were depicted in the Ramesseum beside the scenes of triumphal return to Egypt and offering the spoils to the Theban gods [52]. In addition, Ramses II mentioned his capture of Ullaza in his inscription in Nahr el-Kalb [6]. Ramses II and Merneptah maintained the Egyptian presence in Ullaza. Alt tentatively proposed that a garrison was built in Ullaza called" Merneptah Hotephirmaat [53]. Ullaza did not appear in the Egyptian sources after the reign of Ramses II. Probably, it was occupied by the Assyrian king Ashur-nasirapli II (883-859). In the recordings of the receipt of tribute from the kings on the Lebanese seacoast, many states in the land of Amurru, including a city called Ma-i-za were found. This name, to be read Wa6-i-za, is most likely a dialectal form of Ullaza [22]. It was, then, ruled by the Persians Achaemenid [54].

\section{Conclusion}

Ullaza was one of the important cities that appeared in the Egyptian sources. It had a strategic port. Thus, the Egyptians were keen on maintaining control over Ullaza, especially during the New Kingdom. It set up a garrison. Accordingly, it was the spearhead of the Egyptian campaigns. The strategic value of Ullaza resulted in the transmission of its dependence among the Egyptians, Mittani, Hittites, and the Amorites.

\section{Endnotes}

(a) Khnumhotep III is known to have held a number of high administrative titles, including vizier, chief steward and overseer of the double granaries, as well as some religious ones, though none were connected to either Hathor or Iunmutef, also he held the title the overseer of an expedition of sailors imi- $r^{\complement} m \check{s}^{\varsigma} n k d w$, dating: Senusret II or Senusret III [1].

(b) Late Bronze Age city in Nuhashshi in Syria, Following his conquest of Nuhashshi c. 1340, the Hittite king
Suppiluliuma I appointed a local man, Takibsharri as ruler of the city [10].

(c) Byblos divided into two parts: the Acropolis populated by senior state officials, and Hinterland populated by peasants, who control the cedar forests, and then control the economy of Byblos, so they had an important role during the Amarna period [55].

(d) This dialogue is very similar to the dialogue between Wenamoun and Zakaria Baal [56]. 


\section{References}

[1] Allen, J., (2008). The historical inscription of Khnumhotep at Dahshur: Preliminary report, BASOR, Vol. 352, pp: 29-39.

[2] Sethe, K., (1926). Die Ächtung feindlicher Fürsten, Völker und Dinge auf Altägyptisc-hen Tongefäßscherben des Mittleren Reiches: nach den Originalen im Berliner Museum / hrsg. und erklärt von Kurt Sethe, Berlin.

[3] Posener, G., (1940). Princes et Pays d'Asia et de Nubie, Brussels; id, (1966). Les textes d'envoutement de Mirgissa, Syria, Vol. 43, pp: 277-287.

[4] Marin, A., (2001). Répertoire Géographique des textes Cunéiformes: Die orts und gewässern-amen der Texte aus Syrien im, 12/2, Ludwig Reichert, Wiesbaden.

[5] Sethe, K., (1906). Urk, IV, Hinrichs, J.C. ScheBuchhandeung, Leipzig.

[6] Simons, J., (1937). Handbook for the study of Egyptian topographical lists relating to Western Asia, Brill, Leiden.

[7] Hess, R., (1984). Amarna proper names, PhD., Hebrew Union College, Jewish Institute of Religion), Israel.

[8] Faulkner, R., (1947). The wars of Sethos I, JEA, Vol. 33, pp: 34-39

[9] Alt, A., (1941). Herren und herrensitze; Pal-ästinas im anfang des zweiten jahrtausends v. Chr, ZDPV, Vol. 64, pp: 21-39

[10] Bryce, T., (2009). The Routledge handbook of the peoples and places of ancient Western Asia, Routledge, London.

[11] Meisler, B., (1947). Palestine at the time of the Middle Kingdom in Egypt, RHJE, Vol. 1, pp: 33-68.

[12] Gardiner, A., (1911). Egyptian Hieratic texts-Series I: Literary texts of the New Kingdom, Part I, Hinrichs, J.C.ScheBuchhandeung, Leipzig.
[13] Albright, W., (1928). The Egyptian empire in the twenty-first century B.C, JPOS, Vol. 8, pp: 223-256.

[14] Dussaud, R., (1940). Nouveaux textes égyptiens d'exécration contre les peuples syriens, Syria, Vol. 21/2, pp: 170-182.

[15] Gauthier, H., (1912). DG., III, IFAO, Cairo.

[16] Helck, W., (1968/69). Zur staatlichen Org-anisation Syriens im Beginn der 18. Dynastie, $A F O$, Vol. 22, pp: 27-29

[17] Redford, D., (2003). The wars in Syria and Palestine of Thutmose III, Brill, Leiden.

[18] Astour, M., (1963). Place-names from the kingdom of Alalab in the North Syrian list of Thutmose III: A study in historical topography, JNES, Vol. 22/4, pp: 220-241.

[19] Gelb, I., (1935). Inscriptions from Alishar and Vicinity, Univ. of Chicago Press, Chicago.

[20] Dussaud, R., (1927). Traduction en langue arabe de l'ouvrage topographie historique de la Syrie antique et médiévale, Presses de l'Ifpo, Paris.

[21] Babelon, E., (1893). Les perses achéménides les satrapes et les dynastes tributaires de leur Empire Cypre \& Phénicie, Feuardent, Paris.

[22] Stieglitz, R., (1991). The city of Amurru, JNES, Vol. 50/1, pp: 45-48.

[23] Mohy-Eldin, A., (2014). KPN (Jbeil) City and its relations with Egypt until the end of the second millennium $B C$., PhD, History dept., Faculty of Arts, Minia Univ., Egypt

[24] Albright, W., (1964). The eighteenthcentury princes of Byblos and the chronology of Middle Bronze, BASOR, Vol.176, pp: 38-46.

[25] Dantong, G., (1998). The relationship of Egypt and Western 
Asia during the Middle Kingdom reflected in the inscription of Amenemhet II from Memphis, JAC, Vol.13, pp: 83-90.

[26] Flammini, R., (2011). De la teoría al análisis de los sistemas-mundo: considera-ciones sobre la interacción entre Egipto, Kerma y Biblos (c. 19851640 a.C.), Antiguo Oriente. Vol.9, pp: 135-166.

[27] Wastlhuber, C., (2013). The relatio-nship between Egypt and the Levant during the $12^{\text {th }}$ dynasty: Four case studies and the generation of prestige, in: De Angelis, F. (ed.), Regionalism and globalism in antiquity: Exploring their limits, Leuven, Paris, pp: 69-93.

[28] Margueron, J., (1994). L'urbanisme de Byblos: Certitudes et problèmes, in: Acquaro, E., Mazza, F., Ribichini, S., Scandone, G. \& Xella, P., (eds.) Biblo. Una città e la sua cultura, CNR, Roma, pp: 13-36.

[29] Dunand, M., (1927). La cinquième campagne des fouilles de Byblos (1926), Syria, Vol. 8/2, pp: 93-104.

[30] Dunand, M., (1939). Fouilles de Byblos I. 1926-1932., Bibliothèque Archéologiqueet historique 24, Paris.

[31] Newberry, E., (1938). Three OldKingdom travellers to Byblos and Pwenet, JEA, Vol. 24/2, pp: 182-184.

[32] Roccati, A., (2015). Iny's travels, in: Biga, M, Cordoba, J., del Cerro, C. \& Torres, E. (eds.), Omaggio a Mario Liverani, fondatore di una nuova scienza, II, Madrid, pp: 225-229.

[33] Marcolin, M. \& Espinel, D., (2011). The Sixth dynasty biographic inscription of Iny: more pieces to the puzzle, in: Bárta, M., Filip C. \& Jaromír, K., (eds.), Abusir and Saqqara in the year 2010, Prague: Czech Institute of Egyptology, Faculty of
Arts, Charles Univ. in Prague, pp: 570-615.

[34] Marcus, E., (2007). Amenemhet II and the sea: Maritime aspects of the Mit Rahina (Memphis) Inscription, $E \& L$.Vol. 17, pp: 137-190.

[35] Ben-Tor, D., (2016). Pharaoh in Canaan: the untold story. Jerusalem: The Israel Museum, Israel.

[36] Aubet, M., (2007). Comercio y colonialismo en el próximo oriente antiguo: Los antecedents colonials del III y II milenios a.C., Bellaterra, Spain.

[37] Vogel, C., (2012). Pharaos verlängerter arm: ägyptische Beamte im auslandseinsatz, in: Beinlich, H. (ed.), Die männer hinter dem könig: 6. Symposion zur ägyptischen Königsideologie, Iphofen, Wiesbaden: Harrassowitz, pp: 151-166

[38] Wastlhuber, C., (2009). Das vorkommen von malku(m)/mēki $(m)$ in den schriftquellen des Mittleren Reiches Hinweise auf Beziehungen zur nrdlichen Levante, in: Schulz, R., Kessler, D., Schulz, R., Ullmann, M., Verbovsek, A., Wimmer, S., (eds.), Festschrift für Prof. Dr. Günter Burkard, ÄAT 76, Wiesbaden. pp: 442-448.

[39] Flammini, R., (2010). Elite emulation and patronage relationships in the Middle Bronze: The Egyptianized dynasty of Byblos, Tel Aviv, Vol.37, pp: 154-168.

[40] Klengel, H., (1992). Syria 3000 to 300 B.C.: A handbook of political history. Akademie-Verlag, Berlin

[41] Morris, E., (2005). The architecture of im-perialism military bases and the evolution of foreign policy in Egypt's New Kingdom, Brill, Leiden.

[42] Redford, D., (1992). Egypt, Canaan and Israel in Ancient Times, Princeton Univ. Press, Princeton.

[43] Abdul-Kader, M., (1959). The administration of Syria Palestine during 
the New Kingdom, ASAE, Vol. 56, pp: 105-137.

[44] Na'aman, N., (1981). Economic aspects of the Egyptian occupation of Canaan, IEJ, Vol. 31, No3/4, pp: 172-185.

[45] Mizrachy, Y., (2012). The eighth campaign of Thutmose III Revisited", JAEI. Vol. 4 (2), pp.24-52.

[46] Spalinger, A. J., (2005). War in ancient Egypt: The New Kingdom, Blackwell, Oxford.

[47] Wells, J., (1986). War in Ancient Egypt, PhD., The Johns Hopkins Univ., Baltimore

[48] Singer, I., (1991). A concise history of Amu-rru, Izre'el Shlomo, S. (ed.) Amurru Akkadian: A Linguistic Study, Vol. II, Atlanta Scholars Press, Atlanta, pp. 135-195

[49] Beckman, G., (1996). Hittite Diplomatic Texts. Atlanta: Scholars Press, Atlanta.

[50] El-Saady, H., (1992). The wars of Sety I at Karnak: A new chronological structure, $S A K$, Vol.19, pp: 285294.
[51] Kitchen, K., (2009). Egyptian NewKingdom topographical lists: An historical resource with "Literary" Histories, in: Brund, P. \& Cooper, L. (ed.) Causing his name to live: Studies in Egyptian epigraphy and history in memory of William $\mathrm{J}$. Murnan, Brill, Leiden, pp: 129-135

[52] Kitchen, K., (1977). Ramesside inscriptions. T, II, Blackwell, Oxford.

[53] Alt, A., (1959). Das stützpunktsystem der pharaonen an der phnikishchen kuste und im syrischen Binnenland, $K S$, Vol. 3, pp: 107-140.

[54] Elayi, J., (1982). Studies in Phoenician ge-ography during the Persian Period, JNES, Vol. 41/2, pp: 83-110.

[55] Altman, A., (1978). The revolutions in Byblos and Amurru during the Amarna period and their social background in: Ramat-Gan, A. (ed.) Bar-Ilan studies in history, Bar-Ilan Univ. press, Israel, pp: 3-24.

[56] Lichtheim M., (1976). Ancient Egyptian literature A book of Readings, II, University of California press, London. 